\title{
Protective Effects of Chives Leaves (Allium Schoenoprasum, L.) Infusion Against Ethylene Glycol and Ammonium Chloride Induced Nephrolithiasis in rats
}

\author{
Ginda Haro ${ }^{1}$, Siti Morin Sinaga ${ }^{1}$, I. Iksen ${ }^{1 *}$, N. Nerdy ${ }^{1}$, Suthinee Theerachetmongkol ${ }^{2}$ \\ ${ }^{1}$ Department of Pharmaceutical Chemistry, Faculty of Pharmacy, University of Sumatera Utara, Medan, Indonesia. \\ ${ }^{2}$ Department of Internal Medicine, Surin Hospital, Surin, Thailand.
}

\begin{tabular}{l} 
ARTICLE INFO \\
\hline Article history: \\
Received on: 06/05/2017 \\
Accepted on: $21 / 06 / 2017$ \\
Available online: $30 / 08 / 2017$ \\
\hline Key words: \\
Anticalculi, Chives, Infuse, \\
Ethylene Glycol, Calcium \\
Oxalate, Atomic Absorption \\
Spectrophotometry.
\end{tabular}

\begin{abstract}
The present day medical management of calculi is either costly or not without side effects. Hence, the search of anti-calculi drugs from natural sources has been assumed greater importance. Chives (Allium schoenoprasum, L.) is a long-lived plant which is very easy to grow. It contained a variety of phytochemical compounds and various minerals. This aim of this research was to evaluate exposed of anti-calculi activity of fresh and dried chives leaves infuse on male albino Wistar rats using $0.75 \%$ ethylene glycol and $2 \%$ ammonium chloride induction method. Animals in treatment group are given $10 \%$ of fresh and dried chives leaves infuse. Anticalculi activity in the chives leaves infuse examined by observing the kidney weight ratio, calcium level in kidney, urinary calcium level, urinary oxalate level, and creatinine serum level. From the data obtained, there were significant differences in treated group from negative control group. The biggest effect of dissolving the calcium oxalate crystal in kidney was the dried chives leaves infuse. Based on the above results, it could be concluded that chives leaves could be an alternative to calculi disease treatment.
\end{abstract}

\section{INTRODUCTION}

Kidney stone or calculi disease has become a rising problem and the third relevant disorder affecting the urinary tract with high recurrence. The majority (up to $80 \%$ ) of all stone is mainly composed of Calcium oxalate. The present day medical management of calculi is either costly or not without side effects. Hence, the search of anti-calculi drugs from natural sources has assumed greater importance (Amin, et al., 2015). Herbal drugs are the oldest sources for the preventing, medication, treatment and even diagnostic tools know to mankind.

\footnotetext{
* Corresponding Author

Iksen, Department of Pharmaceutical Chemistry, Faculty of Pharmacy, University of Sumatera Utara, Medan, Indonesia.

Mailing address: Jl. A.R.Hakim No. 179, Medan 20216, Indonesia

Phone: +6283189352214, Email: ikseniksen08 @ gmail.com
}

Most of the drugs commonly used today are herbal origin. Herbal drugs are inexpensive and effective with fewer side effects (Manimala, et al., 2014). Chives (Allium schoenoprasum L.) is a long-lived plant which is very easy to grow (Iksen, 2017). Chives can be used to treat many diseases such as vaginal discharge, constipation and infectious germs in the intestines, speed up the blood flow, prevent blood clotting, antioxidants, breast cancer, antiinflammatory and antihypertensive (Andarwulan and Faradilla, 2012; Amalia, et al., 2008; Jalkumar and Jasmine, 2016; Parvu, et al., 2014; Sachinm, et al., 2010) .

Chives leaves contain a variety of phytochemical compounds included alkaloids, flavonoids, glycosides, steroids, tannins and various minerals such as potassium, magnesium and sodium, which contains high potassium is believed to dissolve calcium oxalate in kidney stones, where one of the main factors affecting solubility calcium is potassium (Al-Snafi, 2014; Iksen, et al., 2017). 
Infusion technique has several advantages when compared with the manufacture of the extract that is cheaper, faster and a tool used quite simple (Alvin, 2015).In our previous study, we used fresh and dried chives leaves infuse to dissolve calcium oxalate and found that chives leaves infuse can dissolve it (Iksen, et al., 2017).

Therefore, the aim of the present study was to evaluate the effect of the anticalculi activity of fresh and dried chives leaves infuse on male albino wistar rats using $0.75 \%$ ethylene glycol and $2 \%$ ammonium chloride induction method.

\section{MATERIALS AND METHODS}

\section{Materials}

Ammonium chloride, Batugin Elixir ${ }^{\circledR}$, demineralized water, ethylene glycol, fresh and dried chive leaves, nitric acid, and the standard solution of calcium $1000 \mathrm{mg} / \mathrm{mL}$

\section{Methods}

\section{Preparation of fresh and dried chive leaves infuse solution}

Chives leaves infusion solution was made with

two kinds of which are fresh and dried chives leaves infuse solution. The dose used was $10 \%$ (both $10 \mathrm{~g}$ of fresh and dried chives leaves voiled in $100 \mathrm{~mL} 90^{\circ} \mathrm{C}$ water) w/ $\mathrm{v}$ in accordance with the infuse criteria in the Indonesian Pharmacopoeia Edition IV.

\section{Selection of Animals for In Vivo Studies}

For the purpose of anticalculi studies, adult male Wistar albino rats weighing around 170 to $180 \mathrm{~g}$ were selected. The animals were acclimatized to standard laboratory conditions and maintained for 12 hours light and dark cycle. They were provided with regular rat chow and drinking water ad libitum. Our Institutional Animal Research Ethics Committees (AREC) Approval No: 697/KEPH-FMIPA/2016.

\section{Animal Groupings}

In this study, animals were divided into five groups, each with five rats. The group I act as normal group. Group II, act as calculi negative control where animals received $0.75 \%$ ethylene glycol with $2 \%$ ammonium chloride in drinking water for 20 days. Group III (positive control) animals received $0.75 \%$ ethylene glycol with $2 \%$ ammonium chloride in drinking water along with Batugin Elixir $^{\circledR}$ drug from the first day till the tenth day. Rats in group IV and $\mathrm{V}$ were treated respectively with fresh and dried chives leaves infuse solution from day eleven till last day.

\section{Parameters Assayed for Anticalculi Studies}

The biochemical parameter for the anticalculi studies were the kidney weight ratio, calcium level in kidney, urine volume, calcium and oxalate level in urine and serum creatinine level. All parameters was analysed by standard procedures.

\section{Preparation of Sample}

Preparation of Calcium Calibration Curve

A total of $5 \mathrm{~mL}$ of $1000 \mathrm{ppm}$ calcium (the mother liquor) was added to a $100 \mathrm{~mL}$ columetric flask and then added aquabidest right to mark boundaries, the obtained raw calcium was $50 \mathrm{ug} / \mathrm{mL}$. Each of $2 \mathrm{~mL}, 4 \mathrm{~mL}, 6 \mathrm{~mL}, 8 \mathrm{~mL}$, and $10 \mathrm{~mL}$ pipetted calcium standard solution $50 \mathrm{ug} / \mathrm{mL}$ in a $50 \mathrm{~mL}$ volumetric flask to obtain successive concentration of 2 ppm; 4 ppm; 6 ppm; 8 ppm and 10 ppm and measured by atomic absorption spectrophotometry at a wavelength of $422.7 \mathrm{~nm}$. Then obtained a calibration curve of calcium

\section{Destruction of Samples}

Each kidney obtained from the rats will be dried in oven $\left(100^{\circ} \mathrm{C}\right)$ for 24 hours and then heated in $540^{\circ} \mathrm{C}$ for eight hours and then diluted with nitric acid and demineralized water

\section{Determination of Calcium Levels in Kidney}

The sample solution that has been prepared with the absorbance measured using flame atomic absorption spectrophotometry at a wavelength of $422.7 \mathrm{~nm}$ for calcium (Iksen, et al., 2017). Absorbance values obtained should be within the range of the calibration curve of calcium standard solution. The calcium level will be calculated based on the regression equation of the calibration curve.

\section{Collection and Analysis of Urine for Biochemical Assays.}

All animals were kept in individual metabolic cages and 24 hours urine samples were collected on $20^{\text {th }}$ day of calculi induction treatment. The volume of urine, urine calcium and oxalate were measured at the respective time points. Animals had free access to drinking water during the urine collection period. A drop of concentrated hydrochloric acid was added to urine before being stored at $-20^{\circ} \mathrm{C}$ until analyzed.

\section{Serum Analysis}

Blood was collected from rats using standard procedure. Separated serum was analysed for creatinine.

\section{Statistical Data Analysis}

Results were given as Mean \pm SEM from five animals in each groups. Comparisons were made by ANOVA method with SPSS 21. P (probability value) $<0.05$ was considered significant.

\section{RESULTS AND DISCUSSION}

\section{Selection of Animals}

Adult male abino Wistar rats were selected to induce nephrolithiasis (calculi) because of the urinary system of male rats resembles that of humans. Previous studies have shown that the amount of calcium oxalate stone deposit in female or young rats 
was significantly less. That is why in this research we used the adult male albino Wistar rats.

\section{Calibration Curve of Calcium}

The calibration curve of calcium has the range for the concentration which were measured on concentration of 2 ppm,4 ppm, $6 \mathrm{ppm}, 8 \mathrm{ppm}$ and $10 \mathrm{ppm}$. The correlation coefficient obtained from this metal can be accepted as the appropriate requirements for the correlation coefficient which should not smaller than 0,995. Coefficient above suggested a linear relationship between the concentration of the metal and absorbance (Iksen, et al., 2017). The calibration curve of calcium is shown in Figure 1.

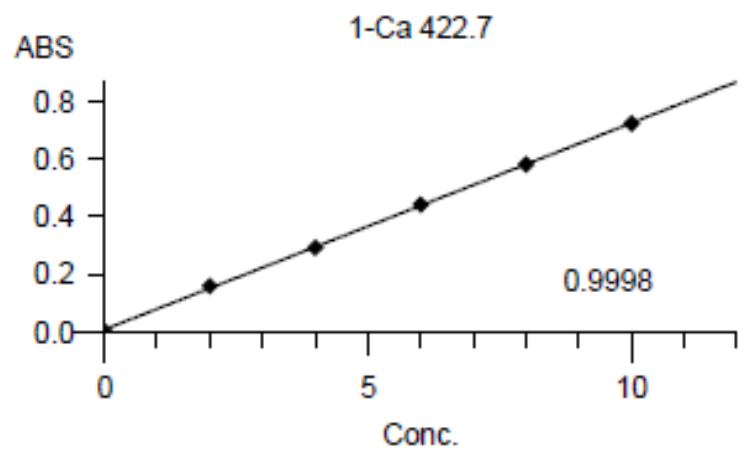

Fig. 1: The calibration curve of calcium standard solution.

\section{The kidney body weight ratio and calcium level in kidney}

Metabolites of ethylene glycol such as glycolaldehyde, glycolate and oxalate can induce tissue damage, hyperoxaluria and the calcium oxalate calculi (Hadjzadeh, et al., 2008).In these studies, chronic administration of $0.75 \%$ ethylene glycol and $2 \%$ ammonium chloride to male albino Wistar rats increased the kidney weight ratio and the calcium level in kidney (Group II/ Control Negative). The calcium level was significantly increased when compared to normal animals are shown on Table 1 and Figure 2.

The calcium levels were decreased while treated with fresh and dried chives infuse solution. The treatment with chives leaves infuse solution significantly decreased the calcium levels. These results indicated that chives leaves infuse treatment shows improvement in renal function compared to the group II/ control negative.

Potassium in chives leaves infuse was believed can dissolve the calcium oxalate precipitate caused by the location of potassium in the Volta's row to the left side from calcium, so it will get rid of potassium calcium oxalate compound to join, and will dissolve calcium compounds. The more to the left of an element in Volta row, the reductant power will getting stronger. This means that the element will be able to reduce ions of the elements from its left side (Anggraini, 2015; Iksen, 2017). The other factor to dissolve calcium oxalate is flavonoids in chives leaves infuse. The other research investigation also said that the effect of inhibiting calculi is from the antioxidant effect of the flavonoids. It seems that flavonoids in chives could play an antioxidant role against oxidative stress that is induced by the ethylene glycol (Shekha, et al., 2015).

Table 1: The biochemical parameter results in kidney.

\begin{tabular}{ccc}
\hline Group & $\begin{array}{c}\text { Kidney weight } \\
\text { ratio } \\
(\mathbf{m g} / \mathbf{1 0 0} \mathbf{g})\end{array}$ & $\begin{array}{c}\text { Calcium level in } \\
\text { kidney } \\
(\mathbf{m g} / \mathbf{g})\end{array}$ \\
\hline Group I (Normal) & $0.66 \pm 0.006$ & $2.587 \pm 0.221$ \\
Group II (Negative Control) & $0.95 \pm 0.03 * \mathrm{a}$ & $4.377 \pm 0.170 * \mathrm{a}$ \\
Group III (Positive Control) & $0.735 \pm 0.025 * \mathrm{~b}$ & $2.815 \pm 0.137 * \mathrm{~b}$ \\
Group IV (Fresh chives leaves infuse) & $0.75 \pm 0.025 * \mathrm{~b}$ & $2.838 \pm 0.091 * \mathrm{~b}$ \\
Group V (Dried chives leaves infuse) & $0.75 \pm 0.011 * \mathrm{~b}$ & $2.726 \pm 0.08 * \mathrm{~b}$ \\
\hline Values are expressed as Mean \pm SEM, $\mathrm{n}=5 ;$ Comparison: a (Group I vs Group \\
II), b (Group II vs Group III, IV, and V); $*$ P<0.05.
\end{tabular}

II), b (Group II vs Group III, IV, and V); * P $<0.05$.

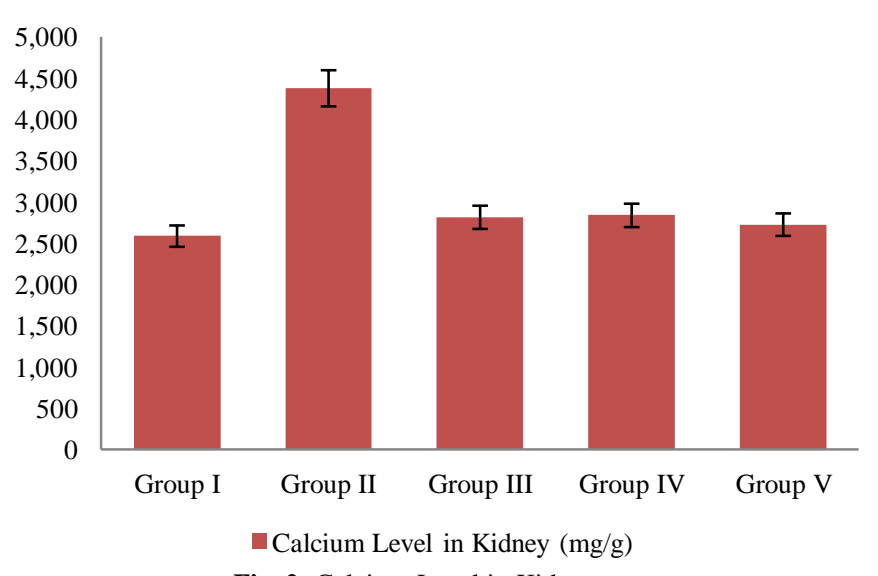

Fig. 2: Calcium Level in Kidney

\section{Effect on the Urinary and Serum Parameters}

The super-saturation of urine is the main reason responsible for the calculi stone forming. The results ethylene glycol and ammonium chloride induction administration increased the level of calcium, oxalate and creatinine level in urine. Ammonium chloride can accelerating stone formation through metabolic acidosis (Iksen, 2017).

The 24 hour excretion of calcium was increased significantly on $20^{\text {th }}$ day in negative control group rather than other treatment group. Similarly increased in urinary oxalate was increased significantly on $20^{\text {th }}$ day in negative control group rather than other treatment group. Simultaneous treatment with fresh and dried chives leaves infuse solution reduced the increase in urinary calcium and oxalate. The level of urinary oxalate and urine volume are shown on Table 2.

In Figure 3, we can see that the creatinine level was increased significantly on $20^{\text {th }}$ day in negative control group compared with other treatment group. This creatinine level was reduced in both positive control and chives leaves infuse solution. 
Table 2: The biochemical parameter results in urine.

\begin{tabular}{|c|c|c|c|}
\hline Group & Calcium Level (mg/24 h) & Oxalate Level (mg/ 24 h) & Volume of Urine (mL) \\
\hline Group I (Normal) & $2.27 \pm 0.58$ & $2.98 \pm 0.18$ & $4.4 \pm 0.40$ \\
\hline Group II (Negative Control) & $5.65 \pm 0.61 * a$ & $6.70 \pm 0.34 * a$ & $2.48 \pm 0.26 * a$ \\
\hline Group III (Positive Control) & $2.72 \pm 0.58 * b$ & $3.83 \pm 0.21 * b$ & $5.94 \pm 0.32 * b$ \\
\hline Group IV (Fresh chives leaves infuse) & $2.87 \pm 0.17 * b$ & $4.11 \pm 0.61 * b$ & $4.8 \pm 0.76^{*} \mathrm{~b}$ \\
\hline Group V (Dried chives leaves infuse) & $2.46 \pm 0.32 * b$ & $3.43 \pm 0.19 * b$ & $5.43 \pm 0.26 * b$ \\
\hline
\end{tabular}

Values are expressed as Mean \pm SEM, $\mathrm{n}=5$; Comparison: a (Group I vs Group II), b (Group II vs Group III, IV, and V); * P<0.05.

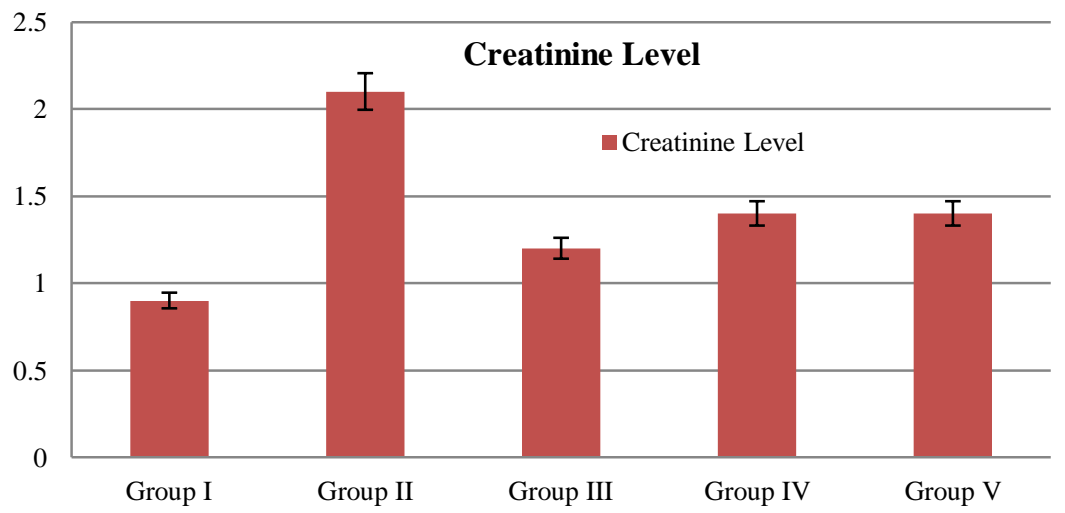

Fig. 3: The creatinine level in blood serum.

\section{CONCLUSION}

From the anticalculi in vivo test result, it can be concluded that fresh and dried chives leaves infuse solution have the potential as anticalculi. It can be seen from the decreased kidney weight ratio, calcium level in the kidney, and the biochemical parameters in urine such as the calcium and oxalate level.

\section{ACKNOWLEDGMENTS}

Administrative Department of Pharmaceutical Chemistry, Faculty of Pharmacy, Universitas Sumatera Utara and Surin Hospital, Thailand.

\section{Financial support and sponsorship: Nil.}

Conflict of Interests: There are no conflicts of interest.

\section{REFRENCES}

Al-Snafi, A. E. Pharmacological Effects Of Allium Species Grown In Iraq. International Journal of Pharmaceuticals and Health Care Research, 2014; 1(4): 132-155.

Alvin, Y. 2015. Analysis of Calcium Oxalate and Calcium Carbonate Solubility in Infuse of Fresh Sow Thistle Leaves (Sonchus arvensis L.) and Sow Thistle Leaves Extract Capsules Dosage By Atomic Absorption Spectrophotometry. Thesis, Faculty of Pharmacy, University of Sumatera Utara.

Amalia, L., Sukandar, E.Y., Roesli, R.M.A., and Sigit, J.I., The Effect of Ethanol Extract of Kucai (Allium schoenoprasum L.) Bulbs on Serum Nitric Oxide Level in Male Wistar Rats. International Journal of Pharmacology, 2008; 4(6): 487-493.

Amin, B., Hanieh, M. F., Alireza, T. H., Naser, T. M., dan Hossein, H. Protective Effects of The Aqueous Extract of Crocus sativus Against Ethylene Glycol Induced Nephrolithiasis In Rats. EXCLI Journal, 2015; 14(4):411-422.

Andarwulan, N., dan Faradilla, R.H.F., Sayuran Fenolik Pada Beberapa Sayuran Indigenous Dari Indonesia, 2012, Bogor: SEAFAST Center, IPB.
Anggraini, T. Potency Of Citrus (Citrus aurantium) Water As Inhibitor Calcium Lithogenesis On Urinary Tract. J.Majority, 2015; 4(1) : 99-104.

Iksen. 2017. The effect of chives (Allium schoenoprasum, L.) Leaves Infuse on The Calcium Salt Solubility Using In Vitro And In Vivo By Atomic Absorption Specthrophotometry. Thesis. Faculty of Pharmacy, University of Sumatera Utara

Iksen, Haro, G., Sinaga, S.M. In Vitro Test of Chive Leaves Infuse (Allium schoenoprasum, L.) on Calcium Oxalate Solubility using Atomic Absorption Spectrophotometry, International Journal of ChemTech Research, 2017; 10(2): 99-102.

Indonesia Pharmacopoeia, Fourth Edition. 1995. Indonesia's Ministry of Health.

Jalkumar,B, and Jasmine, R. A Review on A Few Medicinal Plants Possessing Anticancer Activity Against Human Breast Cancer. International Journal of PharmTech Research, 2016, 9(3): 333-365.

Manimala, M., Clement, W. A., Sheik, M. A. A., Purushoth, P.Effect of Concnia grandis on Ammonium Chloride and Ethylene Glycol Induced Urolithiasis In Rats. Int. J. Drug Dev. \& Res, 2014, 6(3):138-146. Parvu, A.E., Parvu, M., Vlase, L., Miclea, P., Mot, A.C., Dumitrescu, R.S. Anti-Inflammatoy Effects Of Allium schoenorpasum, L. Leaves. Journal of Physiology and Pharmacology, 2014, 65(2):309-315.

Sachinm U.R., Priyanka, R.P., and Sagar,R.M.. Use of Natural Antioxidants to Scavenge Free Radicals: A Major Cause of Diseases. International Journal of PharmTech Research, 2010, 2(2): 1074-1081.

Shekha, M.S., Ismail, T.F., and Aziz, F.M. Anti-Urolithiatic and Anti-Oxidant Effects of Fenugreek on Ethylene Glycol-Induced Kidney Calculi in Rats. Jordan Journal of biological Sciences, 2015; 8(2):159-163.

\section{How to cite this article:}

Haro G, Sinaga SM, Iksen I, Nerdy N, Theerachetmongkol S. Protective Effects of Chives Leaves (Allium Schoenoprasum, L.) Infusion Against Ethylene Glycol and Ammonium Chloride Induced Nephrolithiasis in rats. J App Pharm Sci, 2017; 7 (08): 222-225. 